\title{
On the possibility of authentic self-expression
}

\author{
Mpho Tshivhase \\ Department of Philosophy University of Pretoria mpho.tshivhase@up.ac.za
}

\begin{abstract}
This article explores self-expression as an (and not the) articulation of one's personhood. The point of this article is to enquire whether expression, when articulated on and for an audience, can be deemed authentic. Self-expression can be revealed and recognised through different modes, and on different platforms. Moreover, most human activities, such as singing, dancing and writing, can be considered acts of self-expression. Face-to-face encounters and social media platforms enable a person to express him/herself, and so, give spectators access to some part of his/her self-understanding as an individual. It is possible that some modes of self-expression have the potential to hinder the authenticity of one's expression. Such a hindrance may reflect a distinction between who someone 'truly' is, and who they would like others to think they are. There thus appears to be a link between someone's motive and his/her authenticity, where platforms for self-expression enable someone to authentically or inauthentically express their distorted or genuine personhood. In view of the possibility of certain modes of self-expression threatening authentic selfexpression, how can authentic self-expression be possible?
\end{abstract}

Keywords: authenticity, inward reflection, personhood, self-authorship, self-expression, selfunderstanding

\section{Introduction}

There are a number of platforms that enable persons to articulate who they understand themselves to be, how they feel, or what they want (and do not want), amongst many other things worthy of being expressed. Some people use therapists to express and make sense of their emotions, thoughts and self-understandings, while others use art - dancing, acting, painting - to express some aspect of their personhood. Some do immoral things, like abusing, raping, stealing, lying or killing persons (and/or animals) to express some aspect they judge to be crucial to their sense of personhood. Given the different platforms available to different individuals, as well as the different senses of personhood that individuals are presumably free to create and express, I aim to use this article to question the possibility of authentic self-expression.

What is particularly interesting about the modes and platforms of self-expression has to do with the way people use social media platforms to express themselves. It is not improbable 
that some of these platforms could hinder the process of authentic self-expression, where such authenticity should not be limited to straightforward or measurable true or false judgements about self-representations.

Authenticity (as it is relevant to this article) is often understood in terms of the idea that it emanates from the manner in which individuals come to cultivate their personhood in interactions with other people. Such authenticity, as Charles Taylor (1991) indicates, is not a process or experience one undertakes in isolation - rather, authenticity has a dialogic structure that necessitates interaction with other people in one's surroundings. The process of authenticity is experienced amongst other people, within society. Understood in this dialogic sense, authenticity should involve the interactive relation and negotiation between a person and society, where the person should ultimately filter what matters to him/her without any imposition from that which stands external to him/her.

This idea of authenticity is useful in limiting the reach of society's control when it comes to self-understanding. It is in the manner that one filters external interference from others that one actually takes part in the process of fostering an authentic style of self-expression. My overarching argument is that representations of one's personhood cannot be regarded as authentic when one expresses it in a manner that is strategically or instrumentally designed to impress or elicit a reaction from an interlocutor or spectator. Similarly, an authentic personhood is not a function of a persona that is instrumental or dominated by the need to 'come across as' or be perceived as a certain person whose characteristics are not aligned with one's genuine personhood.

The aim, in the first section of the article, is to explain self-expression and personhood with a view to clarifying the link between the two concepts. Some forms of self-expression can reveal an aspect of our personhood, but such forms of self-expression ought not to be confused with the personhood they represent. The section that follows offers a discussion on authenticity as it will be applied when inquiring into the possibility of authentic selfexpression. Furthermore, I will illustrate how authentic and inauthentic self-expression manifest in society. The conclusion will show that, as tricky as self-expression may be, it is not impossible to articulate it in as close to authentic a manner as possible.

\section{Self-expression and personhood}

Self-expression, in general, involves an articulation of something to do with the person who is doing the expressing. Any aspect of the person can be expressed in a number of ways, many of which successfully provide a glimpse of the person's sense of self-understanding. For the purpose of this article, self-expression will be taken to refer to a representation of one's personhood - or at least a part thereof. It is important to clearly delineate both the differences and the relations between personhood and self-expression. 
It would be a mistake to think of the two concepts as identical, since one is about who one is and the other has to do with the representation of who one is. In other words, selfexpression is a matter of representation, while personhood is a matter of self-understanding and self-determination. In other words, personhood can be understood as the subject of self-expression because, in a sense, it is the personhood of the individual that is conveyed in an instance of self-expression.

Debates on personhood usually involve questions about the criteria that determine who and what a person is. The issue here is: What criteria do we refer to in order to define a person? The focus here has to do with what persons are, or, put differently, what characteristics constitute a person. Establishing personhood is a matter of recognising a composition of characteristics that make up a person, so that any being that lacks such characteristics is not considered a person. This, as Timothy Chappell $(2011,2-3)$ explains, is known as the criterialist view of persons. Criterialism implies criterial possessions (e.g. rationality, selfconsciousness, emotionality, capacity to communicate, moral agency, and the ability to valuate one's life) to be necessary and sufficient conditions for personhood (Zagzebski 2001, 405-412). Although the criterial view of persons is designed to illustrate personhood as a condition for moral accountability and right bearing, it sadly excludes children, handicapped and terminally ill individuals who fail to meet the criterial properties put forward for personhood (Chappell 2011, 2-3).

The most obvious problem with the criterial view of persons is that it is exclusionary and, as Chappell (ibid, 4-6) indicates, the criterial view is not compatible with real-time interaction, since individuals do not inspect a checklist before recognising the other as a person. Instead, for Chappell (ibid.), we already interpret beings as persons before we confirm that they possess those properties proposed by criterialism.

While the criterial view is useful in distinguishing persons from animals and other inanimate things (see Rosenthal 2000, 225-229), it falls short in defining personhood in a way that coincides with our experience of, or the way we approach, persons in everyday encounters as it focuses on the 'what-ness' of persons. The legitimate way of addressing a person is not by determining what, but who a person is. When we talk of self-expression, we should therefore be concerned with representing the 'who-ness' of a person, not his/her 'whatness'.

Another way of outlining personhood involves characterising him/her as an individual whose existence is not limited to their biological make-up. In other words, a person is not just a human being who meets certain criteria, as laid out by the criterialist view of persons. The African view of personhood is not directly related to most of the criteria mentioned above - at least not in the view championed by Kwasi Wiredu (1992, 199-200), who views personhood as a relational and processual event. According to Ifeanyi Menkiti (1984, 172$174,178-179$ ), it is possible for one to fail at becoming a person (see also Gyekye 1991, 319). This means that personhood is an achievement whose success is not guaranteed. 
Dismas Masolo $(2010,172)$, another proponent of the African view of personhood, concedes that personhood is communalistic and morally loaded. Viewed in this way, personhood is realised when someone conducts their life in a way that is morally virtuous and, so, humanly excellent.

The African view of persons grants an individual personhood when $s /$ he conducts $\mathrm{him} /$ herself in a manner that is morally acceptable to the community. Thus, this view offers individuals the moral means to acquire personhood. Nonetheless, it still addresses the 'who' aspect of persons. In addition, the African view of persons accounts for a kind of personhood that is not static, thereby giving individuals a chance to foster their own personhood within relational settings.

On the individualist normative account of personhood that I support, personhood consists of self-understanding that ought not to be imposed on the person by things that exist outside of the self, such as society in general. Self-understanding pertains to a narrative sense of self that can be said to precede the essence of one's personhood. In other words, one cannot truly cultivate personhood prior to some instance of self-understanding.

Representations of the ideas individuals have of themselves are based on the results of the way one interprets one's personhood. Self-understanding is not limited to introspection - 'a process by which people have focused access to their own mental states' (Rosenthal 2000, 201). To gain self-understanding one does not simply observe one's mental states and say: ' $\mathrm{Hmm}$, given the contents of my mental states this is who I am - I can conclude on the constitution of my personhood.' No, we interrogate our mental states in order to arrive at a 'sensible' account of who we are. That is to say that in order to understand who you are, you have to go beyond simply having access to, and recognising, certain mental states because you remain nothing until you understand yourself. Mental states are not enough for you to understand who you are. The point is, there is nothing true of you prior to or outside of the many ways in which you understand yourself, hence it is necessary to interrogate your mental states in order to arrive at a definition of who you are.

Furthermore, persons are inescapably social beings who are always already situated from the moment of existence. That is to say, persons are always embedded within a society and do not exist in isolation from others (Taylor 1991, 32). In fact, the process of fostering personhood would be poor if engaged in without interaction with others. Society provides a frame within which one can experiment with one's sense of personhood (Lötter 1998, 181).

Society also concretises some constraints that are part and parcel of our situatedness; these constraints include our history, culture and family. Our self-understanding is dialogic, in part because it takes into account these elements of our existence (ibid, 184). One cannot understand oneself by completely ignoring these facts. For instance, an individual cannot authentically determine his personhood by ignoring his ethnicity, as 'it is a permanent 
feature of human life' - he also cannot escape this fact about his personhood as it a history that persists over generations (ibid, 187-192).

Although personhood and self-expression are related in a mutually supportive way, selfexpression and personhood are two different things. Personhood is, in part, what one articulates when expressing oneself, while self-expression is one's representation through speech, action or written words. We cannot express what we do not know and so we must attain self-understanding in order for us to be truly expressive of our personhood - a personhood that is fostered as part of deliberative self-determination.

Mark Migotti $(1992,241)$ captures the difference between self-expression and personhood succinctly when he writes that

the projects of self-determination and self-expression are mutually supportive; the latter enables the former to be coherently construed without appeal to external reasons ... and engaging in the former is a necessary condition of successfully engaging in the latter.

The relation between personhood (arrived at through self-determination) and selfexpression is clearly not one of identity, but one that is complementary in that selfexpression has nothing to express if one lacks a sense of personhood; personhood here is the content of expressiveness. In short, personhood and self-expression are not one and the same thing, but they complement each other.

\section{Authenticity}

I have explained personhood and stated that self-expression has to do with the articulation of who one is - or at least an aspect thereof. I am not assuming here that all instances (or activities) of self-expression articulate everything about one's personhood. On the contrary, I think that an instance of self-expression represents aspects of who one is. Given that my concern is whether the picture one paints of oneself in self-representation is painted, so to speak, in an authentic way, it is necessary to capture the sense of authenticity I have in mind when asking this question. I will use this section to sketch the view of authenticity which I will be applying in this article.

Authenticity has often been understood to mean originality and genuineness, which implies something that it is 'true'. To say of an individual that he is authentic would mean that the particular individual truly represents himself (Guignon 2008, 277). That is to say, an authentic person professes to be who he truly is. Being who one is, in the metaphysical sense, is inescapable. It would be odd to say that the person typing these words on the keyboard at this moment is not really me. Being myself in this sense is not a choice, nor is it an achievement. It is my body that I recognise as myself and it is always really me who performs certain acts through time and space. However, this is a straight-forward way of thinking about authenticity. There is another sense of authenticity, one that has to do with personhood. 
When applying authenticity in relation to one's personhood, authenticity denotes one's expression of who one really is. The issue here is that it is possible for some of one's thoughts and actions to not be truly one's own, and can so be viewed as a betrayal of one's personhood. We tend to think that there are some things that are truly expressive of our personhood, and others that are not (Guignon 2004, viii). When someone is loyal to those things that are true to their personhood, we judge them to be authentic. They are inauthentic when their acts are guided by other people's ideas of who they should be.

Authenticity plays out in a social space that is often characterised by a number of dichotomies, i.e., public vs. private, and/or individual vs. society, amongst others. The relation between society and the individual is one that I think can threaten or strengthen one's authenticity. But, in every case, one cannot become authentic in isolation from other people. I think it is the interactions persons have with others that create the space necessary for constructing an authentic self. The social space enables one to engage with others and reflect on those engagements in light of one's personhood (Guignon 2008, 279; Taylor 1991, 32-35). Introspection then becomes necessary for filtering out those aspects of society which help to maintain one's personhood and those which corrode it. The element of introspection gives us another characteristic of authenticity, i.e., interiority/inwardness.

Authenticity is self-referential and accounts for one's existence internally, and so it does not essentially include reference to others (Baugh 1988, 478-479; Cohen 1993, 114-115; Erickson 1995, 124). Charles Taylor (1991, 29-31) states that conditions for authenticity include creation and discovery, originality, and interrogation of societal rules as well as personal values. The requirements he suggests are openness to horizons of significance and self-definition. These conditions and requirements confirm the self-referential element of authenticity. This self-referential aspect comes out strongly in Taylor's view of authenticity; in his view there is 'an original way of being human' that is distinctly one's own:

There is a certain way of being human that is my way. I am called upon to live my life in this way, and not in anyone else's. But this gives a new importance to being true to myself. If I am not, I miss the point of my life, I miss what being human is. (ibid, 28-29)

Taylor points out two things: the importance of the ideal of authenticity and the fragility of authenticity. It is this fragility that makes authenticity susceptible to external pressures that aim for or promote conformity. One becomes inauthentic when guided by the need to fit one's life to what conformity demands - 'I can't even find the model to live by outside myself. I can find it only within' (ibid, 29). This idea of originality in authorship of personhood is also present in Charles Guignon's view of authenticity:

To say that a person is authentic is to say that his or her actions truly express what lies at their origin, that is, the dispositions, feelings, desires, and convictions that motivate them. Built into this conception of authenticity is a distinction between what is really going on within me - the emotions, core beliefs, and bedrock desires that make me the person I am - and the outer avowals and actions that make up my being in the public world. (Guignon 2008, 278) 
Understood in this way, being authentic entails not allowing someone else to lead your life for you. The idea of authenticity supports the validity of one's self-understanding and interpretation of self-worth and meaning in life, and so gives one character. A life is usually deemed authentic when it is led from the inside (Kymlicka 1988, 183). Authenticity implies becoming and being faithful to one's true self, with a refusal to live according to an externally prescribed life plan to ensure that one achieves happiness and fulfilment (Reisert 2000, 307).

This idea of inward self-determination refers to a life led in accordance with the things (actions, desires, intentions and values) that one believes add significance to life. This inward process involves introspection where one interrogates not just societal values, but also one's personal beliefs about what is good (Kymlicka 1988, 184). It is not enough to prescribe one's self-determination and the values that guide the authentic self. It is important to believe in those values, as a lack of faith in one's own principles or ideals in relation to significant matters, can limit self-reflection and choice (ibid, 195). Instances of a lack of faith become evident when one seeks self-confirmation from things or persons external to oneself (ibid.).

It is possible to think that persons value authenticity precisely because it allows them to foster and maintain their original way of being. In truth there is no materialist gain in authenticity. One does not become wealthier or sexier by being authentic. Instead, one attains access to the inner self that guides one's conduct and deliberation processes (Guignon 2008, 278). Authenticity should prevent one's personhood from losing its selfreferential quality and stop one from referring to others in order to derive personal meaning and value. An authentic individual's personhood is not something that can be imparted by God or granted by physiological make-up. Divine or physiological personhood is not originally one's own in the sense that one does not construct it, nor is it constructed in one's own interest. Authenticity presupposes an original way of being (Cooke 1997, 250), where the source of that original way of being is the self in question, not someone else. To live according to an external source is to 'miss the point of what being human is for me' (Taylor $1991,29)$. Personhood that is determined by anything other than the self in question cannot be deemed authentically personal.

There are some objections to authenticity, especially the inward or self-referential aspect of it. Theodor Adorno $(1973,70)$ worries that what he calls the 'liturgy of inwardness' conceals the altering and mimetic nature of a person, which is constitutive of the individual. For Adorno (ibid.), the idea of authenticity is grounded in a view of persons as transparent to themselves and capable of choosing well for themselves. In the same line of thinking, Michel Foucault $(1983,237)$ cautions against viewing authenticity as involving a process of searching for the hidden self. For Foucault it makes no sense to think of persons as existing in pursuit of a hidden real personhood somewhere out there. In this view, an individual should engage in a process of constructing his personhood, rather than living as if the self 
has been given to him from some authority, so that his task in life becomes searching for his true personhood (ibid.). Foucault rejects the idea of a pre-existing essence of man, that is rationality, in favour of the idea of freedom as a precondition for fostering authenticity.

Another concern involves conceptions about the individual's relation to society and the dichotomies that the idea of authenticity is built on. The problem is that dichotomies such as conformity vs. independence, individual vs. society or inner-directedness vs. otherdirectedness paint a misleading picture about the condition of the person as separate from her surroundings. To see a person as separate from her environment is to deny the connection that exists between the person and her community (Sisk 1973, 62; Slater 1970, $15)$. Herein the issue is that one cannot have a complete or well-rounded sense of self if one lives a life divorced from society.

The three objections -1 ) of concealing the altering and mimetic nature of a person, 2) the existence of a hidden authentic self that one must spend one's life searching for, and 3) a life divorced from community - hold true if we accept personhood as a static, unchanging thing that one creates in isolation from other people. My view of authenticity, which is adopted from Taylor, is not one that negates the relationship between the individual and society. Rather, my view is that society should not interfere in an individual's process of personhood formation to the extent that the person becomes displaced as the author of one's own personhood. My contention is that society cannot be the source of one's personhood, as that takes away one's own way of being. Following Taylor, I agree that persons come to understand themselves through engaging with others in dialogue. Such dialogue can only occur within society. One should not create one's personhood in isolation, as it would not yield a well-rounded self-understanding.

In essence, authenticity places emphasis on how a person constructs his personhood. It is important for the person to be his own source of personhood and not look to others to lead his life for him. This is not to say that a person should not interact with others. On the contrary, he should interact, but without simply taking in everything others have to offer like a sponge. Individuals should judge what others say about them against what they think of themselves, and so interrogate their self-interpretations as they construct their personhood to arrive at a fuller understanding of themselves. The relationship with others is crucial, but so is originality in self-authorship.

In this section I set out to provide a view of authenticity that is relevant to the question I posed regarding the possibility of authentic self-expression. The view I settled on is the one provided by Charles Taylor (1991, 28-29), wherein authenticity is a matter of inward selfauthorship that occurs, in part, through interactions with others in society. For a person to be authentic she has to define herself and go about her life in her own original way, not in a way determined by someone else. Authenticity would enable her to create her own recipe for life, with the power to modify her desires, values and conduct as she progresses in pursuit of her true inner self. In this way, authenticity supports the notion of self- 
authorship, which signifies the idea of someone living out her life, as opposed to simply living out a life that is readily planned out for her by someone else. The ideal of authenticity focuses on the manner in which someone constructs their own personhood. And the manner that is in line with authenticity is based on inward reflection of one's selfunderstanding, which should lead one to foster a self-determined personhood instead of a predetermined one.

\section{Authentic self-expression}

So far I have argued that self-expression has to do with the articulation of one's personhood. I defined the kind of personhood that people display through self-expression. The idea that personhood is what we articulate through self-expression answers the second question which I put forward as important for answering the main question, namely: Is authentic self-expression possible? In this section I illustrate authenticity in relation to selfexpression and personhood, and suggest that authentic self-expression is indeed possible.

It is not obvious in every instance that self-expression is always about the articulation of one's personhood. Whether personal or political, the concern is whether the self-expression of a given person can be authentic. By authentic, I do not suppose that there is a hidden, objectively true personhood out in the universe that one must pursue and so direct one's entire life in search of that hidden true self. My concern is not with the search for an authentic self-expression in the sense of an existing self-expression awaiting discovery. The focus here is on the sense of authenticity that is concerned with how a person comes to express him/herself. One can express oneself to conform to other people's expectations, which could be judged to be inauthentic, or one could represent oneself on one's own terms and be judged authentic. It is this sense of authenticity that I suspect can be hindered by the social interaction that goes on in social media. With advances in technology, I believe the fragility of authenticity is becoming more apparent on different levels.

Interest in the authenticity of self-expression is fueled by the substantial social influences that people are confronted with every day. It is not impossible for people to become confused about what they are expressing to others and whether their expressions about themselves are truly representative of who they are. As mentioned earlier, self-expression is essentially an articulation of one's personhood, where such personhood can be informed by society but should not be defined by society. I will argue that self-expression can be both authentic and inauthentic, and so can one's personhood. I will illustrate at least two ways in which self-expression, as it relates to personhood, can manifest inauthentically or authentically.

Mediated self-expression is easy to mold into whatever one desires, even if it is not true. We hear of such cases quite often where an obese person expresses herself as a person with an athletic body, or an underage girl represents herself as an adult. There are even cases of older women portraying themselves as younger girls in order to get attention from 
younger, sexier men. Cases of mediated self-expression point toward a kind of representation that manifests as a performance which could be dissociated from reality and is thus inauthentic. The abovementioned cases of mediated self-expression are straightforward examples of inauthentic self-expressions that occur as a matter of falsity.

Furthermore, it is not impossible for a person to express an authentic personhood inauthentically. Someone can create a personhood authentically and autonomously, but express it in an inauthentic manner. A person who defines herself in her own way and does so autonomously should arrive at an authentic state of being. However, such a person can express her authentic personhood in a manner that is not motivated by her own interpretation of the best way to express herself, or she can express it with the view to influencing people's reactions towards her in a certain way. The point is, an authentic personhood can be misrecognised and misrepresented, for instance, expressing oneself for instrumental reasons.

The kind of instrumental self-expression that is evident in society is depicted in the case of poet/musician Ntsiki Mazwai,1 who posed nude for an issue of Marie Claire magazine's (2008) campaign against women being raped and assaulted because they wore mini-skirts2 (Madikwa 2008). There is no question that her posing nude is an expression of some aspect of her personhood. Nevertheless, does this particular instance of self-expression count as authentic? I think there are two possible ways of looking at Mazwai's nude expression of herself.

From one perspective, Mazwai's self-expression has to do with looking at her motive for expressing herself. Her naked self-expression may have been a performance meant to elicit a reaction from society, whether it is raising awareness about nakedness not being an invitation to rape, or raising money to help those who have been assaulted. She was provocatively aiming to raise money. Therefore, her posing naked was instrumental. One cannot help but wonder if she would have posed naked for the picture if there were no reward for her supporting the cause. In any case, the fact that her self-expression was primarily instrumental makes it, to some extent, inauthentic.

This perspective on the authenticity of Mazwai's pose depends largely on the driving force of her expression. One cannot deny that a concern for gender issues could be a part of her personhood - perhaps her concern for others captures something of who she is. One also cannot deny the possibility that Mazwai is proud of her body. In addition, it is true that what we observe on the photograph is truly her body, which makes her metaphysically authentic.

There could be another reason for Mazwai's nude self-expression: suppose that she identifies fully with a political identity - particularly one that does not support violence against women. In this case one could not label her self-expression as authentic, since it displays some aspect of her personhood. One could argue that what Mazwai displayed could be taking a so-called relational stance towards women (Nozick 2006, 151-154), which 
may be influenced by her self-understanding as a woman and her being moved by something virtuous in her character to show complete support for the cause. Her articulation of self may be temporarily tied to her political views, and it is not clear that this would make it inauthentic.

In essence there are, among many other possible causes, two reasons for Mazwai expressing herself through nudity: one supposes that she identifies fully with a political identity, and that she is motivated to grab people's attention. Given these two reasons, it is clear that judging another person's authenticity - whether in self-expression or in the personhood expressed - may be incompatible with the very idea of an inwardly generated authenticity. Perhaps the only judgement we can make is a moral one about the nudity in question, and not so much the authenticity of her support for a cause, or even the authenticity of her self-expression.

Ultimately, one cannot know definitively whether another person is expressing herself authentically or not. There is no third-person standpoint on who is (or is not) being authentic - or better yet, what type of self-expression counts as authentic. Only the person in question who expresses herself can be the judge of that. There is no standard of measure that can help another individual verify her authenticity. There are no objective criteria for discerning/discriminating authentic from inauthentic self-expression. In my view, the absence of a third-person perspective does not detract from the possibility of authentic selfexpression; it merely poses a challenge regarding the verification and perhaps the objective recognition of the authenticity of another person's self-expression, whether this occurs face-to-face or is mediated via social networks.

\section{Conclusion}

The idea of self-expression we should aim for, can be authentic when the individual who articulates it does so for reasons other than instrumental ones. Authentic self-expression is discernable in instances where one is not living merely by responding to circumstances. Nonetheless, the true recognition of the authenticity of one's self-expression is only available to the individual who is representing himself; only he can judge the authenticity of his self-expression, because he has a first-person perspective.

Nevertheless, authentic self-expression does not simply derive its authenticity from the authenticity of one's personhood, but is authentic because things that stand outside the self do not direct it. Society should not dictate how one should articulate one's personhood. However, one cannot express one's personhood authentically if one fails to sift through things that are not reflective of who one is. The moment someone gives up their power to self-author their personhood, they allow their self-expression and personhood to be prescribed by something external to the self. 
Furthermore, there seems to be a moral demand on the individual, to be truthful in his/her expressiveness. This demand is implied by the fact of the limited (or complete lack of) means to verify authenticity. It is up to the individual expressing himself to do so honestly and earnestly. And all that the interlocutors or spectators can do is to speculate about the authenticity of such expressions.

Finally, it seems there is more work to be done; the fact that others cannot verify the authenticity of someone's self-expression could be said to take something away from the value of authenticity. This seems to beg the question whether a value such as authenticity is significant when there is no way of verifying its presence. Though, what seems to complicate the issue of authenticity is not so much its possibility, but rather how we recognise and verify authenticity.

\section{Acknowledgment}

I owe a debt of gratitude to the three reviewers who took the time to read my work and provide constructive feedback on improving the article. In addition, I could not have completed this article without the support and encouragement that Mariekie Burger afforded me - thank you so very much for being patient and for reading my drafts. I also thank Rafael Winkler-significant sections of this article benefitted greatly from your interrogation of my ideas. Lesego Buyeye, thank you for your willingness to be my sounding board.

\section{Notes}

1. Mazwai was not the only person who posed nude for the magazine -21 other people also did so. However, I mention her alone here because she was the only one who posed without concealing her private parts, and so, some interpreted her picture as being akin to soft porn.

2. Just to provide a background, there were incidents of women being assaulted the Noord taxi rank in Johannesburg, where the perpetrators cited the mini-skirts women wore as an invitation for sex - non-consensual sex.

\section{References}

Adorno, T. 1973. The jargon of authenticity. Trans. K. Tarnowski and F. Will. Evanston: Northwestern University Press.

Baugh, B. 1988. Authenticity revisited. Journal of Aesthetics and Art Criticism 46: 477-487.

Chappell, T. 2011. On the very idea of criteria for personhood. Southern Journal of Philosophy 49(1): 1-27.

Cohen, R.A. 1993. Authentic self-hood in Heidegger and Rozenzweig. Human Studies 16: 111-128. 
Cooke, M. 1997. Authenticity and autonomy: Taylor, Habermas, and the politics of recognition. Political Theory 25: 258-288.

Erickson, R.J. 1995. The importance of authenticity for self and society. Symbolic Interaction 18: 121-144.

Foucault, M. 1983. On the genealogy of ethics: An overview of work in progress. In Michel Foucault beyond structuralism and hermeneutics, ed. H.L. Dreyfus and P. Rabinow, 229-252. Chicago: University of Chicago Press.

Guignon, C. 2004. On being authentic. London: Routledge.

Guignon, C. 2008. Authenticity. Philosophy Compass 3: 277-290.

Gyekye, K. 1991. Person and community in African thought identities. In Philosophy from Africa: A text with readings, ed. P.H. Coetzee and A.P.J. Roux, 317-336. Cape Town: Oxford University Press.

Kymlicka, W. 1988. Liberalism and communitarianism. Canadian Journal of Philosophy 18: 181-203.

Lötter, H.P.P. 1998. Personal identity in multicultural constitutional democracies. South African Journal of Philosophy 17(3): 179-197.

Madikwa, Z. 2008. Celeb poet strips to the bone. Sowetan Live. http://www.sowetanlive.co.za/sowetan/archive/2008/02/22/celeb-poet-strips-to-the-bone (accessed March 7, 2015).

Masolo, D.A. 2010. Self and community in a changing world. Indiana: Indiana University Press.

Menkiti, I.A. 1984. Person and community in African traditional thought. In African philosophy: An introduction, ed. R.A. Wright, 171-181. New York: University Press of America.

Nozick, R. 2006. The examined life: Philosophical meditations. New York: Simon \& Schuster Paperbacks.

Reisert, J.R. 2000. Authenticity, justice and virtue in Taylor and Rousseau. Polity 33: 305330.

Rosenthal, D. 2000. Introspection and self-interpretation. Philosophical Topics 28(2): 201233.

Sisk, J.P. 1973. On being an object. Harper's Magazine 247: 60-64. 
Slater, P.E. 1970. The pursuit of loneliness: An American culture at the breaking point. Boston: Beacon Press.

Taylor, C. 1991. The ethics of authenticity. Cambridge: Harvard University Press.

Wiredu, K., 1992. Moral foundations of an African culture. In Person and community:

Ghanaian philosophical studies I, ed. K. Wiredu and K. Gyekye, 193-206. Washington, DC: Council for Research in Values and Philosophy.

Zagzebski, L. 2001. The uniqueness of persons. Journal of Religious Ethics 29: 401-423. 